\title{
Correlation of Bioassay Crop Growth with Cinmethylin and Chlorimuron Application Rates for Two Soils
}

\author{
T.G. Boucounis and T. Whitwell ${ }^{2}$ \\ Department of Horticulture, Clemson University, Clemson, \\ SC 296344375
}

\section{J.E. Toler ${ }^{3}$ \\ Department of Experimental Statistics, Clemson University, Clemson, SC 296344375}

Additional index words. herbicide residue, multiple cropping system, Sorghum bicolor, Gossypium hirsutum, Glycine max, Phaseolus vulgaris, Sinapis arvensis, Hibiscus esculentum, Zea mays, Cucumis sativus, Citrullis lanatus, Cucurbita pepo, Raphanus sativus

\begin{abstract}
Ten crops were evaluated for potential use as field bioassay species for cinmethylin and chlorimuron application rates in two soil types. Cinmethylin injured sweet corn (Zea mays L.) and grain sorghum [Sorghum bicolor (L.) Moench] at concentrations as low as $0.28 \mathrm{~kg} \cdot \mathrm{ha}^{-1}$ on either soil type, while broadleaf crops were tolerant. Chlorimuron injured sweet corn, grain sorghum, radish (Raphanus sativus L.), cucumber (Cucumis sativus L.), and watermelon [Citrullis lanatus (Thunb.) Mansf.] at rates $\geq 2.5 \mathrm{~g} \cdot \mathrm{ha}^{-1}$, and squash (Cucurbita pepo $\mathrm{L}$.) at rates $\geq 5.0 \mathrm{~g} \cdot \mathrm{ha}^{-1}$ on a Dothan sand. In a Congaree silt loam, chlorimuron injured cucumber at rates $\geq 5.0 \mathrm{~g} \cdot \mathrm{ha}^{-1}$, sweet corn, watermelon, and squash at rates $\geq 10 \mathrm{~g} \cdot \mathrm{ha}^{-1}$, and grain sorghum, radish, and cotton (Gossypium hirsutum $\mathrm{L}$.) at rates $\geq 20 \mathrm{~g} \cdot \mathrm{ha}^{-1}$. Soybean and snapbean (Phaseolus vulgaris L.) were tolerant to chlorimuron in both soil types. Cinmethylin activity was not altered by soil type, but with chlorimuron greater crop injury was observed in the Dothan sand than in the Congaree silt loam. Sweet corn and grain sorghum were the most sensitive indicator species to cinmethylin and cucumber was the most sensitive to chlorimuron in both soils. Plant emergence and population alone are not valid indicators for crop tolerance to herbicides. Quantitative measurements such as shoot dry weight were more indicative of crop susceptibility to chlorimuron than plant populations. Chemical names used: exo -1-methyl-4-(1-methylethyl)-2 -[(2-methylphenyl) methoxy]-7-oxabicyclo[2.2.1]heptane (cinmethylin); 2-[[[](4-chloro-6-methoxy-2-pyrimidinyl)amino] carbonyl]amino] sulfonyl]benzoic acid (chlorimuron).
\end{abstract}

Multiple cropping systems and the introduction of new, persistent herbicides have increased the potential for crop injury from herbicide carryover. Because of the difficulty of extraction and quantitative detection of newer herbicide residues via laboratory analysis (Shell Development, 1985; Zahnow, 1986), bioassays are a major detection tool for herbicide residues. Documentation of indicator crops and quantification of herbicide residue levels that injure crops would be useful in multiple cropping systems.

Cinmethylin herbicide was developed by

Received for publication 26 Apr. 1989. Technical Article 2960, South Carolina Agricultural Experiment Station, Clemson, Univ. This work was supported in part by USDA/CRS Special Grants Program Agricultural Adjustment in the southeast through Alternative Cropping System Grant no. 88-34156-3357. The cost of publishing this paper was defrayed in part by the payment of page charges. Under postal regulations, this paper therefore must be hereby marked advertisement solely to indicate this fact.

'Graduate Research Assistant, Dept. of Horticullure.

${ }^{2}$ Professor, Dept. of Horticulture.

${ }^{3}$ Instructor, Experimental Statistics. soil, especially 2:1 montmorillonitic clays, greatly influences the activity of certain herbicides. High soil $\mathrm{pH}$ has generally been associated with increased persistence and phytotoxicity of certain herbicides. For example, Jackson and Banks (1986) reported increasing activity and persistence of chlorimuron with increasing soil $\mathrm{pH}$. Goetz et al. (1986) found that chlorimuron's volubility increased with increasing $\mathrm{pH}$, and adsorption to soil particles decreased as moisture levels increased. Chemical hydrolysis is one of the major soil degradation pathways for the sulfonylurea herbicides, which include chlorimuron (Beyer et al., 1988). The rate of chlorimuron hydrolysis decreases with increasing soil $\mathrm{pH}$; therefore, at higher $\mathrm{pH}$ less is degraded and the herbicide is more persistent and phytotoxic.

Because herbicides are affected by many soil factors and field bioassays are being recommended for determining herbicide carryover, more information is needed to correctly select the most sensitive species. The objective of this research was to evaluate the response of grain sorghum, sweet corn, soybean, snapbean, radish, okra, cotton, cucumber, watermelon, and squash to various soil application rates of cinmethylin and chlorimuron in two soil types.

Field experiments were established in May 1986 at two locations and were repeated in June of the same year. Plots were located near Blackville, S. C., at the Edisto Research and Education Center on a Dothan sand (Plinthic Paleudults), and at Clemson, S. C., on a Congaree silt loam (Typic Udifluvents). Chemical and physical analysis data of the soils from each location are shown in Table 1.

A split-plot design was used with herbicide treatments as the main plot and crops as subplots. Main plots were $1.5 \times 6.0 \mathrm{~m}$ and subplots were two 1.5 -m-long rows within the main plot. Ten crops (Table 2) were seeded at a depth of $3 \mathrm{~cm}$. Herbicides were applied immediately thereafter to the soil surface to avoid dilution of the dosage as occurs with soil incorporation. Herbicides were applied using a $\mathrm{CO}_{2}$-pressurized backpack sprayer, in a spray volume of $187 \mathrm{li}$ ter.ha' ${ }^{-1}$, and at $152 \mathrm{kPa}$. Treatments were replicated four times.

Chlorimuron was applied at 2.5,5.0, 10.0, and $20.0 \mathrm{~g}$ a.i./ha and cinmethylin was applied at $0.14,0.28,0.56$, and $1.12 \mathrm{~kg}$ a.i./ ha. The highest rate represents the labeled use rate, with other rates decreasing proportionately to simulate possible residual hercreases (Lo and Merkle, 1984). Weber et al. (1974) observed that the clay fraction in a

Table 1. Physical and chemical characteristics of soils in field study.

\begin{tabular}{lccccccc}
\hline \hline Location & Soil type & $\mathrm{pH}^{2}$ & $\begin{array}{c}\text { Organic } \\
\text { mattery } \\
(\%)\end{array}$ & $\begin{array}{c}\mathrm{Sand}^{\mathrm{x}} \\
(\%)\end{array}$ & $\begin{array}{c}\text { Silt } \\
(\%)\end{array}$ & $\begin{array}{c}\text { Clay } \\
(\%)\end{array}$ & $\begin{array}{c}\text { CEC }^{\mathrm{w}} \\
(\mathrm{meq} / 100 \mathrm{~g})\end{array}$ \\
\hline Clemson & $\begin{array}{c}\text { Congaree silt loam } \\
\text { Edisto }\end{array}$ & 5.6 & 3.8 & 46 & 51 & 3 & 23.54 \\
Dothan sand & 5.5 & 1.0 & 92.1 & 7.7 & 0.2 & 7.50 \\
\hline
\end{tabular}

${ }^{2}$ Soil $\mathrm{pH}$ was determined using a 1 soil $: 1$ water suspension.

yoil organic matter content was determined using the Whatley-Black method.

${ }^{x}$ Mechanical (physical) analysis was performed by the hydrometer method.

"Cation exchange capacity (CEC) was determined by $1.0 \mathrm{~N}$ ammonium acetate extraction buffered at $\mathrm{pH} 7.0$. 
Table 2. Taxonomic name, cultivar, and seeding rate for crops evaluated.

\begin{tabular}{lllr}
\hline \hline Crop & \multicolumn{1}{c}{ Taxonomic name } & \multicolumn{1}{c}{ Cultivar } & Seed/m \\
\hline Grain sorghum & Sorghum bicolor (L.). Moench & Gro-Agri BR1333 & 30 \\
Cotton & Gossypium hirsutum (L.) & NK235 & 8 \\
Soybean & Glycine max (L.) Merr. & Foster & 15 \\
Snapbean & Phaseolus vulgaris (L.) & Strike & 10 \\
Radish & Sinapis arvensis (L.) & Champion & 15 \\
Okra & Hibiscus esculentum (L.) & Clemson Spineless & 8 \\
Sweet corn & Zea mays (L.) & Merit & 9 \\
Cucumber & Cucumis sativas (L.) & Sprint 440 S & 9 \\
Watermelon & Citrullis lanatus (Thunb.) Mansf. & Crimson Sweet & 12 \\
Summer squash & Curcurbita pepo (L.) & Dixie Hybrid & 10 \\
\hline
\end{tabular}

Table 3. Influence of cinmethylin on sweet corn and grain sorghum population (plants/0.5 mind and shoot dry weight $\left(\mathrm{g} / 0.5 \mathrm{~m}^{2}\right) 30$ days after application to a Congaree silt loam or Dothan sand. ${ }^{2}$

\begin{tabular}{|c|c|c|c|c|c|c|c|c|}
\hline \multirow{3}{*}{$\begin{array}{l}\text { Cinmethylin } \\
\text { rate }\left(\mathrm{kg} \cdot \mathrm{ha}^{-1}\right)\end{array}$} & \multicolumn{4}{|c|}{ Congaree silt loam } & \multicolumn{4}{|c|}{ Dothan sand } \\
\hline & \multicolumn{2}{|c|}{$\begin{array}{c}\text { Plant } \\
\text { population }\end{array}$} & \multicolumn{2}{|c|}{ Shoot wt } & \multicolumn{2}{|c|}{$\begin{array}{c}\text { Plant } \\
\text { population }\end{array}$} & \multicolumn{2}{|c|}{ Shoot wt } \\
\hline & $\mathrm{CRN}$ & GS & $\mathrm{CRN}$ & GS & $\mathrm{CRN}$ & GS & $\mathrm{CRN}$ & $\mathrm{GS}$ \\
\hline$\overline{0.0}$ & 4.4 & 16.6 & 22.9 & 20.2 & 6.7 & 29.9 & 18.2 & 33.2 \\
\hline 0.14 & 3.8 & 16.1 & 20.1 & 20.0 & 5.9 & 26.5 & 16.3 & 26.7 \\
\hline 0.28 & 3.9 & 14.0 & 20.2 & 18.0 & 4.9 & 19.0 & 3.6 & 11.9 \\
\hline 0.56 & 1.0 & 14.3 & 1.4 & 6.2 & 3.4 & 13.3 & 2.6 & 5.1 \\
\hline 1.12 & 0.9 & 5.1 & 1.8 & 2.0 & 1.4 & 7.8 & 1.7 & 3.6 \\
\hline Response $^{y}$ & $\mathrm{~L}$ & c. & $\mathrm{c}$ & $\mathrm{L}$ & $\mathrm{L}$ & $\mathrm{c}$ & $\mathrm{L}$ & $\mathrm{c}$ \\
\hline
\end{tabular}

${ }^{2} \mathrm{CRN}=$ sweet corn, $\mathrm{GS}=$ grain sorghum.

Linear $(\mathrm{L})$ or curvilinear $(\mathrm{C})$ response was significant $\mathrm{a} \boldsymbol{P}=0.05$.

Table 4. Influence of chlorimuron on plant population (plants $\left./ 0.5 \mathrm{~m}^{2}\right)$ and shoot dry weight $(\mathrm{g} / 0.5$ $\left.\mathrm{m}^{2}\right) 30$ days after application to a Congarec silt loam.

\begin{tabular}{|c|c|c|c|c|c|c|c|c|c|c|}
\hline $\begin{array}{l}\text { Chlorimuron } \\
\text { rate }\left(g \cdot h a^{-1}\right)\end{array}$ & $\mathrm{CRN}^{\mathrm{z}}$ & GS & SOY & SNP & RAD & OKR & CTN & CUC & WAT & SQU \\
\hline & \multicolumn{10}{|c|}{ Plant population } \\
\hline 0.0 & 4.4 & 16.6 & 8.1 & 5.5 & 10.2 & 4.1 & 4.3 & 3.4 & 5.6 & 5.5 \\
\hline 2.5 & 3.6 & 17.1 & 6.8 & 4.7 & 11.0 & 4.2 & 4.3 & 4.8 & 4.3 & 5.3 \\
\hline 5.0 & 4.0 & 14.9 & 8.1 & 4.9 & 11.8 & 4.8 & 4.3 & 5.0 & 4.4 & 5.1 \\
\hline 10.0 & 3.5 & 14.9 & 7.5 & 5.4 & 9.4 & 5.6 & 4.3 & 4.3 & 5.2 & 5.1 \\
\hline 20.0 & 4.1 & 15.6 & 6.8 & 6.3 & 9.8 & 3.7 & 5.1 & 4.7 & 4.6 & 4.5 \\
\hline Responsey & NS & NS & NS & NS & NS & NS & NS & NS & NS & NS \\
\hline & \multicolumn{10}{|c|}{ Shoot dry weight } \\
\hline 0.0 & 22.9 & 20.2 & 16.4 & 16.7 & 7.0 & $9.6^{\circ}$ & 4.3 & 13.5 & 13.6 & 21.3 \\
\hline 2.5 & 18.4 & 20.5 & 16.0 & 17.7 & 6.6 & 10.2 & 3.9 & 13.7 & 12.4 & 19.9 \\
\hline 5.0 & 22.7 & 20.2 & 17.0 & 16.7 & 6.9 & 9.8 & 4.2 & 6.0 & 12.6 & 20.8 \\
\hline 10.0 & 6.3 & 19.4 & 16.4 & 16.8 & 6.6 & 11.2 & 3.9 & 8.4 & 5.9 & 9.8 \\
\hline 20.0 & 2.9 & 10.1 & 15.8 & 17.6 & 2.2 & 7.4 & 1.8 & 4.7 & 4.7 & 10.5 \\
\hline Response & L & $\mathrm{C}$ & NS & NS & $\mathrm{L}$ & NS & $\mathrm{L}$ & $\mathrm{L}$ & $\mathrm{L}$ & $\mathrm{C}$ \\
\hline
\end{tabular}

${ }^{2} \mathrm{CRN}=$ corn, $\mathrm{GS},=$ grain sorghum, $\mathrm{SOY}=$ soybean, $\mathrm{SNP}=$ snapbean, $\mathrm{RAD}=$ radish, $\mathrm{OKR}=$ okra, $\mathrm{CTN}=$ cotton, $\mathrm{CUC}=$ cucumber, $\mathrm{WAT}=$ watermelon, $\mathrm{SQU}=$ squash .

'Linear (L) or curvilinear (C) response was significant at $P=0.05$ or no response (NS).

Table 5. Influence of chlorimuron on plant population (plants/0.5 mí) and shoot dry weight ( $\mathrm{g} / 0.5$ $\left.\mathrm{m}^{2}\right) 30$ days after application to a Dothan sand.

\begin{tabular}{|c|c|c|c|c|c|c|c|c|c|c|}
\hline $\begin{array}{l}\text { Chlorimuron } \\
\text { rate }\left(\mathrm{g} \cdot \mathrm{ha}^{-1}\right)\end{array}$ & $\mathrm{CRN}^{2}$ & $\mathrm{G} \mathrm{S}$ & SOY & SNP & RAD & OKR & CTN & CUC & WAT & SQU \\
\hline & \multicolumn{10}{|c|}{ Plant population } \\
\hline 0.0 & 6.7 & 29.9 & 11.9 & 5.9 & 9.1 & 5.5 & 5.6 & 5.8 & 11.8 & 8.2 \\
\hline 2.5 & 1.3 & 27.0 & 11.7 & 4.1 & 0.0 & 5.9 & 4.5 & 1.9 & 10.5 & 8.0 \\
\hline 5.0 & 1.5 & 29.1 & 10.1 & 5.4 & 0.0 & 5.5 & 5.1 & 0.8 & 13.6 & 3.6 \\
\hline 10.0 & 0.6 & 21.9 & 12.0 & 4.9 & 0.0 & 4.9 & 4.3 & 0.3 & 5.4 & 3.5 \\
\hline 20.0 & 0.6 & 23.1 & 11.0 & 4.7 & 0.0 & 4.7 & 0.7 & 0.8 & 3.7 & 2.9 \\
\hline Response $^{y}$ & $\mathrm{C}$ & NS & NS & NS & $\ldots x$ & NS & L & $\mathrm{C}$ & $\mathrm{L}$ & $\mathrm{C}$ \\
\hline \multicolumn{11}{|c|}{ Shoot dry weight } \\
\hline 0.0 & 18.2 & 33.1 & 10.7 & 5.8 & 3.3 & 4.2 & 4.7 & 11.2 & 35.9 & 27.2 \\
\hline 2.5 & 0.5 & 14.1 & 10.2 & 5.6 & 0.0 & 1.3 & 1.2 & 0.9 & 14.3 & 26.1 \\
\hline 5.0 & 0.9 & 15.5 & 11.5 & 5.7 & 0.0 & 0.6 & 1.0 & 0.7 & 12.9 & 7.2 \\
\hline 10.0 & 0.3 & 11.8 & 10.6 & 6.0 & 0.0 & 0.9 & $1 .(0)$ & 0.0 & 10.5 & 5.4 \\
\hline 20.0 & 0.8 & 10.6 & 10.4 & 5.6 & 0.0 & 0.8 & 0.9 & 0.6 & 10.0 & 3.6 \\
\hline Response & $\mathrm{C}$ & $\mathrm{L}$ & NS & NS & $\ldots$ & $\mathrm{C}$ & $\mathrm{C}$ & $\mathrm{C}$ & $\mathrm{C}$ & $\mathrm{L}$ \\
\hline
\end{tabular}

${ }^{2} \mathrm{CRN}=$ sweet corn, $\mathrm{GS}=$ grain sorghum, $\mathrm{SOY}=$ soybean, $\mathrm{SNP}=$ snapbean, $\mathrm{RAD}=$ radish, $\mathrm{OKR}=$ okra, $\mathrm{CTN}=$ cotton, $\mathrm{CUC}=$ cucumber, $\mathrm{WAT}=$ watermelon, $\mathrm{SQU}=$ squash.

Linear (L) or curvilinear (C) response was significant a $P=0.05$ or no response (NS).

${ }^{x}$ Response analysis inappropriate, since herbicide killed all plants. bicide levels.

Plots were irrigated overhead $(15 \mathrm{~mm})$ following herbicide application and as needed for the duration of the experiment. At 30 days after treatment, plant populations were counted and above-ground plant parts were harvested, dried at 35C for 7 days, and dry weights were" recorded. Data were subjected to regression analysis and significant responses were indicated at $P=0.05$. Interactions were not significant between experiments, herbicides, and locations, so all data were combined.

Shoot growth (dry weight) and plant populations of broadleaf crops were not affected by cinmethylin in either soil type (data not shown). Other researchers have reported excellent broadleaf crop safety with cinmethylin (Forney et al., 1986; Monaco and Bonanno, 1985). However, With an increase in cinmethylin rate, sweet corn plant populations were reduced linearly in both soil types (Table 3). Corn shoot weight response was curvilinear in the silt loam soil and linear in the Dothan sand. Severe growth reductions occurred at cinmethylin levels $\geq 0.28 \mathrm{~kg} \cdot \mathrm{ha}^{-1}$ in the Dothan sand and $\geq 0.56 \mathrm{~kg} \cdot \mathrm{ha}^{-1}$ in the Congaree silt loam. In general, grain sorghum's response to increasing cinmethylin rate was similar to that of sweet corn.

The sensitivity of sweet corn and grain sorghum to cinmethylin indicates that they would be effective bioassay species for cinmethylin persistence and activity. The herbicidal activity of cinmethylin was similar for the two soil types. Cinmethylin is held on the surface of soil colloids by physical sorption only (Shell Chemical, 1985), therefore, its activity is less affected by soil type. Cinmethylin is also readily displaced from soil colloids by water. These characteristics allow cinmethylin to exhibit similar activity on two markedly different soils.

Chlorimuron activity differed on the two soil types. In the Congaree silt loam, chlorimuron did not affect plant populations of any crop, but shoot growth was reduced for seven of the ten crops (Table 4). Soybean, snapbean, and okra shoot weight were not influenced by any rate of chlorimuron. Growth reductions were primarily linear for the injured crops except for grain sorghum and squash. Crops affected by chlorimuron were extremely stunted. The most sensitive species was cucumber, with shoot growth reductions observed at chlorimuron levels $\geq 5.0$ g-ha-'. Sweet corn, watermelon, and squash shoot weight was reduced at chlorimuron rates $\geq 10.0 \mathrm{~g} \cdot \mathrm{ha}^{-1}$. Grain sorghum, cotton, and radish were less sensitive; biomass reductions were observed only at the $20.0 \mathrm{~g} \cdot \mathrm{ha}^{-1}$ level.

Chlorimuron injury to crops was greater in the Dothan sand (Table 5) than in the silt loam. However, soybean and snapbean were tolerant to all chlorimuron rates, with no reduction in population or shoot growth. Chlorimuron virtually eliminated sweet corn, radish, and cucumber populations at the lowest rate. Cotton and watermelon populations were reduced linearly, while squash populations declined at a decreasing rate with in- 
creasing herbicide levels (curvilinear response). Grain sorghum and okra populations were unaffected by chlorimuron rates. In this coarse-textured soil, chlorimuron reduced shoot growth of sweet corn, grain sorghum, radish, okra, cotton, cucumber, watermelon, and squash. Severe growth reductions were expressed at the lowest chlorimuron rate by all these crops, except squash. Severe growth restriction occurred for squash with herbicide rate $\geq 2.5 \mathrm{~g} \cdot \mathrm{ha}^{-1}$

The lack of correlation between shoot growth reductions and plant population may be explained in the mode of action of chlorimuron. This herbicide inhibits acetolactate synthase (Ray, 1986), which is necessary for valine, leucime, and isoleucine biosynthesis. Susceptible plants emerge but become stunted and eventually die due to lack of basic amino acids. Because plant growth is a better indicator of chlorimuron injury, bioassays to detect this herbicide should evaluate plant growth rather than plant emergence.

Other researchers have reported chlorimuron tolerance among crops in the Fabaceae family, while susceptible crops are often injured by minute amounts of chlorimuron (Lloyd et al., 1986; Reynolds et al., 1985). In this study, chlorimuron was deleterious to seven of ten crops in a Congaree silt loam, and eight of ten crops in a Dothan sand. Because cucumber was sensitive to the lowest rate of chlorimuron on both soil types, this species may be effectively used as a bioassay crop.

\section{Literature Cited}

Beyer, E. M., M.J. Duffy, J.V. Hay, and D.D. Schluetter. 1988. Suflonylureas, p. 117-189. In: P.C. Kearney and D.D. Kaufman (eds.). Herbicides chemistry, degradation, and mode of action. Marcel Dekker, New York.

Forney, D. R., J.W. May, and L.T. Brown. 1986. Weed control programs with cinmethylin. Proc. Southern Weed Sci. Soc. 39:72.

Goetz, A., R.E. Walker, G. Wehtje, and J.A. McGuire. 1986. Mobility and soil solution characterization of chlorimuron in Alabama soils. Proc. Southern Weed Sci. Soc. 39:423.

Jackson, M. N., and P.A. Banks. 1986. Effect of soil $\mathrm{pH}$ on the behavior of chlorimuron. Proc. Southern Weed Sci. Soc. 39:421.

Lloyd, R. W., J.W. Keeling, and J.R. Abernathy. 1986. Efficacy of new herbicides on nutsedge and rotational crops. Proc. Southern Weed Sci. Soc. 39:473.

Lo, C. C., and M.G. Merkle. 1984. Factors affecting the phytotoxicty of norflurazon. Weed Sci. 32:279-283.

Monaco, T. J., and A.R. Bonanno. 1985. Cinch: a promising new herbicide for vegetable crops. Proc. Southern Weed Sci. Soc. 38:120.

Ray, T.B. 1986. Sulfonyl urea herbicides as inhibitors of amino acid biosynthesis in plants. Trends in Biomed. Sci. 11:160-163.

Reynolds, D. B., R.B. Westennan, and D.S. Murray. 1985. Rotational crop response to DPXF6025, dimethazone, and imazaquin following their application to soybeans. Proc. North Central Weed Cont. Conf. 40:68.

Shell Chemical Co. 1985. Cinch herbicide technical manual. Agricultural Chemical Div. Houston, Texas.

Shell Development Co. 1985. Determination of residues of SD 95481 in crops, soil, and water. Biological Sciences Research Center. Modesto, Calif.

Weber, J. B., S.B. Weed, and T.W. Waldrop. 1974. Effect of soil constituents on herbicide activity in modified soil field plots. Weed Sci. 22:5:454-
459.

Zahnow, E.W. 1986. Analysis of DPX-F6025 in soil by liquid chromatography. E.I. du Pont de Nemours and Co., Inc. Agricultural Products Dept., Research Div. Expt. Sta., Wilmington, Del.

HoRTSCIENCE 25(5):538-540. 1990.

\title{
Response of Apple Cultivars to Fumigation with Methyl Bromide
}

\author{
M. Meheriuk, A.P. Gaunce, and V.A. Dyck \\ Research Station, Agriculture Canada, Summer-land, B.C. VOH 1ZO, \\ Canada
}

Additional index words. firmness, disorders, diphenyiamine, taste, Malus domestics

Abstract. 'Golden Delicious', 'Delicious', and 'Spartan' apples (Malus domestics Borkh.) showed a high, moderate, and low tolerance, respectively, to methyl bromide fumigation. Incidence of external and internal disorders increased, in most instances, with longer storage periods after fumigation treatments and with longer exposure times to the fumigant. Dips in diphenylamine before fumigation reduced, but did not prevent, disorders. Fumigation had little effect on firmness and no effect on soluble solids content or titratable acidity. Methyl bromide concentrations with a low risk of disorder development were 32 to $64 \mathrm{~g} \cdot \mathrm{m}^{-3}$ for 'Golden Delicious', 32 to $48 \mathrm{~g} \cdot \mathrm{m}^{-3}$ for 'Delicious', and $32 \mathrm{~g} \cdot \mathrm{m}^{-3}$ for 'Spartan', all at $10 \mathrm{C}$ for 2 hours.

Quarantine regulations in many countries require imported fruit to be free of specific insects. Fumigation of fruit with methyl bromide $(\mathrm{MB})$ can be an effective means to kill insects. Several reports on fumigation indicate differing susceptibilities among apple cultivars to MB injury (Phillips and Monro, 1939; Kenworthy and Gaddis, 1946; O'Loughlin and Ireson, 1977; Sanford, 1962; Moffitt, 1971). Other factors reported to influence susceptibility of apples to injury are weather (Claypool and Vines, 1956), location (O'Loughlin and Ireson, 1977), harvest date (Sanford, 1962), and dips in diphenylamine (DPA) solutions (Sproul et al., 1976). Physiological responses to MB treatments include accelerated respiration (Claypool and Vines, 1956) and higher rates of softening (Southwick, 1945). This paper presents results obtained from a 3-year study on British Columbia-grown apples fumigated with $\mathrm{MB}$ at several doses and examined at specific intervals after treatment. The purpose of this study was to develop procedures for MB fumigation of apples that were lethal to codling moth (Cydia pomonella L.) larvae and eggs but not harmful to the fruit. Firmness, soluble solids content, acidity, flavor, and incidence of external or internal disorders (in

Received for publication 18 Apr. 1989. Agriculture Canada Research Station, Summerland, B. C. contribution no. 735 . We gratefully acknowledge the assistance of J.W. Hall in the statistical evaluations. The cost of publishing this paper was defrayed in part by the payment of page charges. Under postal regulations, this paper therefore must be hereby marked advertisement solely to indicate this fact. the presence or absence of DPA) were evaluated.

'Golden Delicious', 'Delicious', and 'Spartan' apples were harvested in 1983 at commercial maturity from mature trees grown at the Summerland Research Station. Box quantities of fruit ( 80 fruits per box) were picked for each treatment and storage period, stored in $0 \mathrm{C}$ air, and then fumigated in Jan. 1984. Fruit in each box at the time of evaluation were randomized into five 15 -fruit subsamples. One sample was immediately evaluated for firmness, percent soluble solids content (SSC), and titratable acidity, and the other four sub-samples were ripened at 20C for 7, days and assessed for external and internal disorders.

Fruit for the 1984 and 1986 experiments were obtained from local packinghouses (five to six grower lots) shortly after harvest. Each grower lot was randomized into box quantities (70 to 80 fruits per box) for each treatment and storage period. AH samples were stored under controlled atmosphere conditions $\left(2 \% \mathrm{CO}_{2}+2 \% \mathrm{O}_{2}\right.$ at $\left.0 \mathrm{C}\right)$ until fumigation. A 15-fruit sub-sample was taken from each box after each storage period (10 to 40 days after fumigation) and evaluated for firmness, SSC, and titratable acidity. The remaining fruit were ripened at 20C for 7 days and assessed for disorders. Flavor evaluations were done on two grower lots of each cultivar in 1986.

Apples from storage were equilibrated for $24 \mathrm{hr}$ at $10 \mathrm{C}$ before fumigation in a $0.98-\mathrm{m}^{3}$ fumigation chamber. Since the maximum capacity of the chamber was 12 boxes of fruit (16 to $20 \mathrm{~kg}$ per box), all fumigations were conducted in consecutive lots of 12 boxes with a load factor of $48 \%$. Preweighed MB 